\title{
Akut Hepatit Tanısıyla İlenen Olguların Değerlendirilmesi
}

\section{The Evaluation of Cases Diagnosed with Acute Viral Hepatitis}

\author{
Emine PARLAK, Zülal ÖZKURT, Mehmet PARLAK \\ Atatürk Üniversitesi Tıp Fakültesi, Enfeksiyon Hastalıkları Anabilim Dalı, Erzurum, Türkiye
}

\section{ÖZET}

Amaç: Akut hepatit olgularının risk faktörleri, bulaşma yolları, epidemiyolojik, klinik özellikleri ve laboratuvar değerlerinin incelenmesi amaçlanmıştır.

Gereç ve Yöntemler: Kliniğimizde 2007-2012 yılları arasında yatııılarak izlenen 60 akut hepatit(AH) olgusu retrospektif olarak değerlendirilmiştir.

Bulgular: Olguların $31(\% 51,7)^{\prime} i$ erkek, $29(\% 48,3)^{\prime}$ u kadındı. 16-60 yaşları arasındaki olguların yaş ortalaması 27,07 idi. A tipi Akut viral hepatitli(AVH-A) hastalarla B tipi AVH'Ii (AVH-B) hastaların yaş ortalamaları arasında istatistiksel olarak anlamlı fark saptandı $(\mathrm{p}<0,001)$. Olgulara en sık ilkbahar ve kış aylarında rastlandı. HAV infeksiyonu $(\% 41,7)$, HBV infeksiyonu (\%43,3), HCV infeksiyonu $(\% 3,3)$, nedeni bulunamayan $(\% 8,3)^{\prime}$ i, HBV koinfeksiyonu $(\% 1,7)$ ve otoimmun $(\% 1,7)$ olarak bulundu. Olguların $45(\% 75)$ 'inde herhangi bir bulaşma yolu ve risk faktörü tespit edilemedi. Olguların yatıs süreleri 3-32 gün arasında değişmekle birlikte, ortalama 14,55 idi. A tipi AVH'li hastalarla B tipi AVH'li hastaların hastane de yatış süreleri arasında $(\mathrm{p}=0.004)$ istatistiksel fark vardı. En sık görülen yakınmalar halsizlik (\%75), iştahsılık $(\% 73,3)$, bulantı -kusma (\%68,3), idrar renginde koyulaşma $(\% 63,3)$ olarak saptandı. Fizik muayenede en sık saptanan bulgular ise hepatomegali $(\% 88,3)$, splenomegali $(\% 61,7)$, ikter (\%85) idi. Bu hasta grupları arasında serum alanin aminotransferaz (ALT), aspartat aminotransferaz (AST), alkalen fosfataz (ALP), gamaglutamiltranspeptidaz (GGT), total ve direkt bilirubin düzeyleri açısından istatistiksel farklılık yoktu. ALT ortalaması 1826,77 U / I (46- 5014), AST ortalaması 1313,02 U/I (65- 6881) total bilirubin ortalama değeri $12,30(1,8-53) \mathrm{mg} / \mathrm{dL}$ olarak bulundu.

Sonuç: Bölgemizde AVH-B'nin yüksek oranı, sosyokültürel değerler, kalabalık ailelerin varlığı ve hijyen kurallarındaki eksikliktendi. Olguların çoğunda risk faktörü tespit edilemedi. AVH-A ve AVH-B olgu saylları birbirine yakındı. AVH-A olguları sayıca artmış ve ileri yaşa kaymıştı. (Viral Hepatit Dergisi 2012; 18(3): 111-4)

Anahtar Kelimeler: Akut viral hepatit, epidemiyoloji, transaminazlar

\begin{abstract}
Objective: The purpose of the study is to evaluated risk factors, transmission routes, epidemiology, clinical features and laboratory analyses of acute hepatitis. Materials and Methods: Sixty acute hepatitis infected cases hospitalized at the our clinic during 2007-2012 were observed retrospectively.

Results: $31(51.7 \%)$ of patients were male and $29(48.3 \%)$ female. The age range was between $16-60$ and the average age was 27.07 . There was a statistical meaningful difference between AVH-A and AVH-B patients age average $(p<0.001)$ The cases mostly were detected seen in spring and autumn. HAV infected patients were found to be $41.7 \%$, HBV infected $43.3 \%$, HCV infected $3.3 \%$, infections with unkown reasons $8.3 \%$, HBV koinfected $\% 1.7$ and otoimmune $1.7 \%$. There was no contagious way and risk factors in 45 patients $(75 \%)$. Hospitalization of the patients was between 3-32 days and it's ovarege was 14.55. There was a statistical meaningful difference between AVH-A and hospitalization period $(p=0.004)$. The mostly observed complaints were weakness $(75 \%)$, anorexia (73.3), nause and vomiting (68.3), darkness of urine color (63.3). The frequent symptoms in physical examination were icterus (\%85), hepatomegaly (88.3\%), splenomegaly $(61.7 \%)$. There was no statistical meaningful difference in ALT, AST, ALP, GGT, total bilirubin, direct bilirubin these patient groups. The ALT average was 1826,77 U / I (46-5014), the AST average was 1313,02 U// (65-6881) and total bilirubin average was 12.30 (1.8-53).

Conclusion: The reason behind AVH-B 's being highly spread are socia-culturel values, big families, lack of hygienic conditions. The risk factors could not be found most of the patients. AVH- A and AVH-B case numbers were almost the same. AVH-A case numbers was increased and patients were infected in older ages. (Viral Hepatitis Journal 2012; 18(3): 111-4)
\end{abstract}

Key words: Acut hepatitis, epidemiology, transaminases 


\section{Giriş}

Akut hepatit, karaciğer hücre nekro-inflamasyonu ile giden bir tablodur. Virüsler, ilaçlar ve alkol en sık nedenleridir. Hemodinamik bozuklukta ortaya çıkan iskemik hepatit ve otoimmun hepatit de diğer akut hepatit nedenleridir (1). Akut hepatitlerin en sık nedeni olan viral hepatitler dünyada ve ülkemizde yaygın olarak görülen önemli bir sağlık sorunudur $(1,2)$. Görülme sıklıkları ve etkenleri ülkelerin sosyoekonomik ve coğrafi özelliklerine göre değişir. Son yıllarda en sık gördüğümüz Hepatit $A$ virüsü(HAV), hepatit $B$ virüsü $(H B V)$, hepatit $C$ virüsü (HCV), hepatit $D$ virüsü (HDV) ve hepatit $E$ virüsü (HEV)' dür. Bunlar dışında hepatit $G$ virüsü $(H G V)$ ve transfusion transmitted virüs (TTV) gibi yeni etkenlerde tanımlanmıştır $(2,3)$.

AVH-A olgularında kronikleşme görülmez. Yetişkinlerde \%20 olguda atipik klinik ve $1 / 1000$ olguda fulminan karaciğer yetmezliğine neden olur. HBV infeksiyonu dünyadaki en önemli sağlık sorunlarından birisidir. Dünyada 2 milyar insan virüsle karşılaşmış ve 350 milyon insan taşımaktadır $(3,4)$. Asemptomatik infeksiyon, siroz, fulminan hepatit ve hepatosellüler karsinoma neden olabilir (5).

Bu çalışmada Ekim 2007- Ocak 2012 tarihleri arasında, Infeksiyon Hastalıkları ve Klinik Mikrobiyoloji servisinde yatırılarak izlenen 60 akut hepatit olgusu retrospektif olarak değerlendirildi. Bu çalışma akut hepatit olgularımızın epidemiyolojik özelliklerini, klinik bulgularını ve laboratuvar değerlerini belirlemek için yapılmıştır.

\section{Gereç ve Yöntem}

Akut hepatit tanısı klinik, biyokimya testleri ve seroloji ile kondu. Serolojide viral hepatit tanısında markerlar için ELISA yöntemi kullanıldı. Semptom ve bulguları akut hepatit ile uyumlu kişilerde anti- HAV IgM, anti-HBclgM, HBsAg, anti HCV, anti HDV pozitifliği arandı. Serolojik olarak anti-HAV IgM pozitif olgular akut hepatit $\mathrm{A}$, anti-HBc lgM pozitif olgular akut hepatit $\mathrm{B}$, anti-HCV ve HCVRNA pozitif olgular akut hepatit $\mathrm{C}$ ve $\mathrm{HBsAg}$, anti-HBC IgM, anti-HDV pozitif olgular akut hepatit delta koinfeksiyonu olarak kabul edildi.

Otoimmun hepatit tanısı, hepatit viruslarla infeksiyon, kan transfüzyonu, aşırı alkol tüketimi, hepatotoksik ilaç alma, Wilson Hastalığı, antitripsin eksikliği, hemakromatozis ve safra yollarını tutan hastalık anamnez ve hastalık bulgularının olmadığı durumda kondu.

Hastaneye ilk girişlerindeki şikâyetleri, klinik özellikleri ve laboratuvar değerleri SPSS-20 programına kaydedildi. Olguların kaydedilen değerleri arasında cinsiyet, meslek, yaş, başvuru mevsimleri, risk faktörlerinin varlığı, bulaş yolları ve hastalık süreleri de vardı. Klinik bulgular Fisher's exact testle, laboratuvar değerleri bağımsız gruplarda t-test yöntemiyle, diğerlerinde ise Mann-Whitney $U$, pearson Chi square testle değerlendirildi. Buna göre $p<0,05$ anlamlı kabul edildi.

\section{Bulgular}

2007-2012 yılları arasında kliniğimizde yatışı yapılan 60 akut hepatit olgusu değerlendirildi. Bunlardan 31(\%51,7)'i erkek,
29(\% 48. 3)'u kadındı. 16-60 yaşları arasındaki olguların yaş ortalaması 27,07 idi. Hepatit A olgularında yaş ortalaması 20,44 $\pm 3,08$, Hepatit B olgularında ise $33 \pm 11,54$ bulundu. A tipi AVH'li hastalarla B tipi AVH'li hastaların yaş ortalamaları arasında istatistiksel olarak anlamlı fark saptandı $(p<0,001)$. Olguların 25 $(\% 41,7)$ 'i HAV infeksiyonu, 26 (\%43,3)'s HBV infeksiyonu, 2 $(\% 3,3)$ 'si HCV infeksiyonu, $5(\% 8,3)^{\prime}$ 'i nedeni bulunamayan, 1 $(\% 1,7)$ 'i HBV koinfeksiyonu, 1 (\%1,7)'i otoimmun grupta yer aldı. Etkenlere göre dağılım Tablo1'de gösterilmiştir.

Olgulara en sık ilkbahar ve kış aylarında rastlandı. AVH-A olguları ilkbaharda \%88, kışın \%8, sonbaharda \%4, AVH-B olguları kışın \%61,5, ilkbaharda \%38,5 oranındaydı. Olguların yatış süreleri 3-32 gün arasında değişmekle birlikte, ortalama 14.55 gün idi. Yatış süresi $\mathrm{AVH}-\mathrm{A}$ olgularında ortalama $12,08 \pm 6,23$ gün, AVH-B için 18,08 $\pm 6,92$ gün idi. A tipi AVH'li hastalarla, B tipi AVH'li hastaların hastanede yatış süreleri arasında $(p=0,004)$ fark istatistiksel olarak anlamlı bulundu.

AVH-A olgularında ALT ortalaması 2032,24 $\pm 1087,29$, AST ortalaması 1565,92 $\pm 1486,33, \mathrm{AVH}-\mathrm{B}$ olgularında ise ALT ortalaması $1756,69 \pm 943,51$, AST ortalaması $1260,27 \pm 887,61$ idi (Tablo 2). Laboratuvar incelemelerinde ortalama hemoglobin değeri 13.77g/dl (7-17 g/dl), lökosit sayısı 7643. 33/mm³ (2200$26000 / \mathrm{mm}^{3}$ ), trombosit sayıs 226333 . 33/ $\mathrm{mm}^{3}$ (35000$431000 / \mathrm{mm}^{3}$ ) olarak bulundu. Olguların transaminaz düzeyleri değerlendirildiğinde ALT ortalaması 1826. 77 U / I (46- 5014), AST ortalaması 1313,02 U/l (65-6881) idi. Total bilirubin ortalaması $12.30(1,8-53) \mathrm{mg} / \mathrm{dL}$, alkalen fosfataz ortalaması 204,35 (71-499) U/I ve GGT ortalamsı ise 152,73 (24-535) U/I olarak hesaplandı. Bu hasta grupları serum ALT, AST, ALP, GGT, total ve direkt bilüribin düzeyleri açısından karşılaştırıldığında aralarında istatistiksel farklılık yoktu (Tablo 3 ).

Olgular meslekleri açısından incelendiğinde öğrenci \% 46,7, serbest meslek \%25, ev hanımı \%23,3 ve memur \%5 olarak tespit edildi (Tablo4).

Altmış olgunun 15 (\%25)'inde bulaş için risk faktörü saptanırken, 45 (\%75) 'inde herhangi bir bulaşma yolu ve risk faktörü tespit edilemedi. Ailede hepatit öyküsü olması, girişim ameliyat anamnezi, diş tedavisi ve şüpheli cinsel temas bulaş açısından saptanabilen risk faktörleri idi.

Semptom ve bulguların sıklığı sırasıyla halsizlik (\%75), iştahsızlık $(\% 73,3)$, bulantı-kusma $(\% 68,3)$, idrar renginde koyulaşma $(\% 63,3)$, ateş $(\% 18,3)$ ve kaşıntı (\%15) olarak saptandı. Fizik muayenede en sık saptanan bulgular ise 53 (\%88,3)'ünde hepatomegali, 37 (\%61,7)'sinde splenomegali, ikter 51 (\% 85) 'inde, subikter 12 (\%20)'sinde, lenfadenopati 2 (\%3,3)'sinde idi (Tablo 5).

\section{Tartışma}

Ülkemizde yapılan çalışmalar cinsiyet açısından incelendiğinde Çolpan ve arkadaşları (6); olguların \%42,4'i kadın, \%57,5'u erkek, Koruk ve arkadaşları (7); \%50 'si kadın, \%50'si erkek, Özkurt ve arkadaşları (8); \%42,7 kadın, \%57,2 erkek, olarak bildirmişlerdir. Bizim çalışmamızda \%51,7'i erkek, $\% 48,3$ 'ü kadındı. AVH-A infeksiyonlarının insidansı cinsiyete 
göre farklılık göstermezken, hepatit B olgularının çoğunu erkekler oluşturmaktadır (9). Bölgelere göre değişmekle birlikte farklılıkları çevre kirliliğine, su ve besin sanitasyonuna, riskli temas ve cinsel tercihlerine bağladık.

Önceki yıllarda erişkin yaş grubunda yapılan çalışmalarda AVH-A oranı AVH-B'den daha az saptanmıştır $(8,10,11)$. Son yıllarda ise AVH-A vakalarında artış saptanmıştır $(4,6)$. Olguların $25(\% 41,7)^{\prime}$ 'i HAV infeksiyonu, 26 (\% 43,3)'sı HBV infeksiyonu, 2 $(\% 3,3)$ 'sinde akut HCV infeksiyonu tanısı konmuştur. Bizim çalışmamızda AVH-A ile AVH-B geçirenlerin oranı birbirine yakındır. Benzer şekilde bir çalışmada da Hepatit $A$ ve $B$ olgularının oranı birbirine yakın saptanmıştır(5). Kliniğimizde yatırılarak izlenen AVH-A olgularının oranı 1994 yılında Taşyaran ve arkadaşlarının (11) çalışmasında \% 28, 2001 yılında Özkurt ve arkadaşlarının (8) çalışmasında \%40,2, bizim çalışmamızda ise \%43,3 olarak bulunmuştur. Hijyenik bölgelerden şehrimize gelen üniversite öğrencilerinde ve mesleğe yeni başlayan öğretmenlerde özellikle salgın dönemlerinde daha fazla görmekteyiz. Orandaki artışı AVH-A'nın çocuk yaş grubunda azalıp, ileri yaşa kaymasına ve okumak veya çalışmak için diğer şehirlerden gelen kişilere bağladık.

Eker ve arkadaşları (5) hepatit A için yaş ortalamasını 21,5, hepatit B için 33 bulmuşlar. Başka iki çalışmada AVH-A olgularında yaş ortalaması daha düşük bulunmuştur $(4,12)$. Çalışmamızda genel yaş ortalaması 27,07, hepatit A olgularında yaş ortalaması $20,44 \pm 3,08$, hepatit $B$ olgularında ise $33 \pm 11,54$ olarak bulundu. A tipi AVH'li hastalarla B tipi AVH'li hastaların yaş ortalamaları arasında istatistiksel olarak anlamlı fark saptandı $(p<0,001)$.Yaş ortalamasının düşüklüğünü $A V H-A^{\prime}$ ıın payının yüksek olmasına bağladık. Çevre ve sosyoekonomik değişime paralel olarak AVH-A'nın ileri yaşa kayması ve semptomatik formun bu yaşlardaki sıklığınında bu durumda payı vardır.

Özkurt ve arkadaşları (8), AVH-A'da yatış süresini $20 \pm 8$ gün, AVH-B'li olgularda ise ortalama hastalık süresi $36 \pm 13$ gün olarak tespit etmişler. Aradaki fark istatistiksel olarak anlamlıymış. Eker ve arkadaşları (4) ortalama yatış süresini 12,5 (3-53) gün, AVH-A olguları için 10,5 gün, AVH-B olgularında ise ortalama 14,8 gün olarak bulmuşlar. Olgularımızın yatış süreleri 3-32 gün arasında değişmekle birlikte, ortalama 14.55 gün idi. Yatış süresi $\mathrm{AVH}$ - A

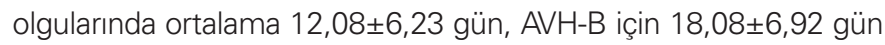
idi. A tipi AVH'li hastalarla, B tipi AVH'li hastaların hastanede yatış süreleri arasında $(p=0,004)$ istatistiksel olarak anlamlı fark bulundu.

Çalışmalarda AVH-A en fazla sonbahar ve kış aylarında görülmüştür $(7,13)$. Çolpan ve arkadaşları $(6)$ ise $A V H-A$ ve $A V H$ -
B'nin de sonbaharda pik yaptığını söylemiştir. Taşkesen ve arkadaşları (12) yaptıkları çalışmada kış \%47,6, sonbahar \%38,1 olarak vermişlerdir. Bizim çalışmamızda AVH-A olguları ilkbaharda \%88, kışın \%8, sonbaharda \%4, AVH-B olguları kışın $\% 61,5$, ilkbaharda \%38,5 oranındaydı. Diğer çalışmalardan farklı olan oranları bölgemizdeki iklim farklılığına, kalabalık yaşamaya, alt yapı eksikliğine ve riskli temasların artışına bağladık.

Koruk ve arkadaşları (7)'nın laboratuvar değerleri irdelendiğinde AVH-A, AVH-B, AVH-C olguları arasında AST, ALT açısından istatistiksel anlamlı farklılık saptamazken, AVH-C olgularında ALP, total bilirubin değerlerini daha düşük bulmuşlar. Ertuğrul ve arkadaşları (4)'da olgular arasında ALT, AST, ALP, GGT, total ve direkt bilüribin düzeyleri açısından istatistiksel farklılık bulmamışlardır. Çolpan ve arkadaşları(6), AVH-A olgularında ALT değerlerini daha yüksek tespit etmişler ama prognozla bir ilişki saptamamışlardır. Eker ve arkadaşları (5), ise AVH-B olgularında ALT ve bilirubin düzeylerini anlamlı yüksek bulmuşlardır. Çolpan ve arkadaşları (6), AVH-A ve AVH-B olgularında AST değerleri arasında anlamlı farklılık bulmamışlardır. Bizim olgularımızda hasta grupları serum ALT, AST, ALP, GGT, total ve direkt bilirubin düzeyleri açısından karşılaştırıldığında aralarında istatistiksel farklılık yoktu.

Semptom ve bulgular irdelendiğinde Eker ve arkadaşlarının (5), her iki hepatit arasında fark olmaksızın tespit ettikleri en sık semptomlar, halsizlik, iştahsızlık, bulantı, kusma, idrar renginde koyulaşma ve sarılık olarak bildirilmiş. Taşkesen ve arkadaşlarının (12) yaptıkları çalışmada en sık şikayetler sırasıyla \% 73,8 sarılık, \%52,3 kusma, \%42,8 ateş, \%38,1 karın ağrısı, \%26,1 halsizlik, \%11,9 iştahsızlık ve \%4,7 bilinç değiş̧ikliği olarak saptanmış. Çalışmamızda en sık başvuru şikâyetleri literatürle uyumlu olarak halsizlik (\%75), iştahsızlık (\%73,3), bulantı -kusma $(\% 68,3)$, idrar renginde koyulaşma $(\% 63,3)$, ateş $(\% 18,3)$ ve kaşıntı (\%15) olarak saptandı.

\section{Tablo 1. Olguların hepatit çeşitlerine göre dağıııı}

\begin{tabular}{lcc}
\hline Hepatit tipi & $\%$ & $\mathbf{n}$ \\
\hline AVH-A & 41,7 & 25 \\
AVH-B & 43,3 & 26 \\
AVH-C & 3,3 & 2 \\
AVH-B+D & 1,7 & 1 \\
Otoimmun & 1,7 & 1 \\
Bilinmeyen & 5 & 8,3 \\
Toplam & 100 & 60 \\
\hline
\end{tabular}

Tablo 2. Hepatit tiplerine göre özellikleri

\begin{tabular}{lccc}
\hline Ortalamalar & AVH-A & Standart sapma & AVH-B \\
\hline AST ortalaması & 1565,92 & 1486,33 & 1260,27 \\
ALT ortalaması & 2032,24 & 1087,29 & 1756,69 \\
Yaş ortalaması & 20,44 & 3,08 & 33,00 \\
Yatıs ortalaması & 12,08 & 6,23 & 11,54 \\
\hline
\end{tabular}

AST: Aspartat aminotransferaz, ALT: Alanin aminotransferaz 


\begin{tabular}{|c|c|c|c|}
\hline \multicolumn{2}{|c|}{ Minimum değer } & \multirow{2}{*}{$\begin{array}{c}\text { Maximum değer } \\
5014\end{array}$} & \multirow{2}{*}{$\begin{array}{c}\text { Ortalama değer } \\
1826,77\end{array}$} \\
\hline ALT & 46 & & \\
\hline AST & 65 & 6881 & 1313,02 \\
\hline T.Bil & 1,80 & 53,00 & 12,30 \\
\hline D.Bil & 0,95 & 52,00 & 9,98 \\
\hline APTT & 23,00 & 79,30 & 34,96 \\
\hline PT & 10,00 & 39,00 & 16,66 \\
\hline Hemoglobin & 7 & 17 & 13,77 \\
\hline lökosit & 2200 & 26000 & 7643,33 \\
\hline ALP & 71 & 499 & 204,35 \\
\hline GGT & 24 & 535 & 152,73 \\
\hline Platelet & 35000 & 431000 & 226333,33 \\
\hline
\end{tabular}

Tablo 4. Buların mesleklere göre dağılımı

\begin{tabular}{lcc}
\hline & $\%$ & $\mathbf{n}$ \\
\hline Öğrenci & 46,7 & 28 \\
Serbest & 25 & 15 \\
Ev hanımı & 23,3 & 14 \\
Memur & 5,0 & 3
\end{tabular}

Tablo 5. Olguların semptom ve bulguları

\begin{tabular}{lccc}
\hline Semptomlar & $\%$ & Bulgular & $\%$ \\
\hline Halsizlik & 75 & hepatomegali & 88,3 \\
İştahsızlık & 73,3 & splenomegali & 61,7 \\
Bulantı-kusma & 68,3 & ikter & 85 \\
Koyu idrar & 63,3 & subikter & 20 \\
Kaşıntı & 15 & lenfadenopati & 3,3
\end{tabular}

Uluğ ve arkadaşları (13), en sık görülen bulguları ikter \%94,2, hepatomegali \%58,1 ve splenomegali \%21,6; Çolpan ve arkadaşları(6), cilt ve skleralarda sarılık \%97,4, hepatomegali $\% 61,4$, splenomegali $\% 13,7$ ve ateş $\% 30,1$; Taşkesen ve arkadaşları (12) ikter \%73,8, hepatomegali \%50, splenomegali \%11,9; Özkurt ve arkadaşları (8), hepatomegali \%84,2, ikter $\% 48,5$, splenomegali $\% 34,0$, ateş $\% 7,4$ ve lenfadenopati $\% 4,1$; Taşyaran ve arkadaşları (11) ise hepatomegali \%93,3, splenomegali \%9,3 olarak bildirmişlerdir. Bizim olgularımızda fizik muayenede en sık saptanan bulgular ise ikter \%85, \%88,3 hepatomegali, \%61,7 splenomegali, subikter \%20, lenfadenopati \%3,3 idi. Klinik bulgular açısından sıklığı farklı olsada veriler literatürle uyumludur. Olgularımızda hepatomegali ve splenomegali oranları literatürden daha yüksek bulunmuştur $(5,6,14)$.
Sonuç olarak, akut hepatitler özelliklede akut viral hepatitler hala önemli bir halk sağlığı sorunudur. Ülkelerin hatta bölgelerin sosyoekonomik ve coğrafi özelliklerine göre prevalansları değişiklik gösterebilir. Bölgemizde önceki çalışmalarla karşılaştırıldığında AVH-A oranı artmıştır ve geçirme yaşı ileri yaşlara kaymıştır. Hastalık, yaş ilerledikçe daha ağır bir klinik tabloya yol açmaktadır. Anamnez, fizik muayene ve laboratuvar sonuçları ile tanı koyabiliriz. Klinik özellikleri benzer olduğu için seroloji hepatit tipini ayırt etmek için önemlidir. Hepatitlerden korunmak için hijyen tedbirleri, eğitim, ve aşılamanın önemli olduğunu düşünmekteyiz.

\section{Kaynaklar}

1. Tabak F. Akut Hepatitler. Istanbul Üniversitesi Cerrahpaşa Tıp Fakültesi Sürekli Tıp Eğitimi Etkinlikleri. Hepato-Bilier Sistem ve Pankreas Hastalıkları Sempozyum Dizisi; 2002. 28: 43-55.

2. Mıstık R. Türkiye'de viral hepatit epidemiyolojisi yayınların irdelenmesi. Tabak F, Balık I, Tekeli E, eds. Viral Hepatit 2007. 1. Baskı. Istanbul: Viral Hepatitle Savaşım Derneği; 2005. p. 10-50.

3. Çivi S, Marakoğlu K, Bitirge M. Viral Hepatitin Epidemiyolojisi ve Maliyet Analizi. Türk Aile Hekimliği Dergisi. 2006; 10(2): 64-70.

4. Ertuğrul Ö, Ertuğrul B, Soner Ü, Çağlar F. Akut Viral Hepatit Infeksiyonlarının Yaş ve Biyokimyasal Özelliklerinin Incelenmesi. ADÜ Tıp Fakültesi Dergisi. 2006; 7(1): 25-7.

5. Eker A, Tansel Ö, Kuloğlu F, Akata F. Akut Viral Hepatit A ve B Olgularının Değerlendirilmesi. Viral Hepatit Dergisi 2005; 10(3): 144-9.

6. Çolpan A, Bodur H, Erbay A, Akıncı E, Öngürü P, Eren S. Akut Viral Hepatit Olgularının Değerlendirilmesi. Viral Hepatit Dergisi 2003; 8(1): 20-24.

7. Koruk ST, Gürsoy B, Koruk I, Zeyrek FY, Unutmaz G, Karaağaç L, Sırmatel F. Akut Viral Hepatit Olgularının Değerlendirilmesi. Viral Hepatit Dergisi 2006; 11(3): 132-7.

8. Özkurt Z, Erol S, Ertek M, Taşyaran MA. Akut viral hepatit olgularının değerlendirilmesi. Viral Hepatit Dergisi 2001; 7: 379-82.

9. Koziel M J, Siddiqui A. Hepatitis B virüs and Hepatitis D virüs. In: Mandell GL, Bennett JE, Dolin R, eds. Mandell, Douglas, and Bennett's Principles and Practice of Infectious Diseases. 6th ed. New York: Churchill Livingstone, 2005: 1864-90.

10. Mıstık R, Balık I. Türkiye'de viral hepatitlerin epidemiyolojisi: Bir meta analiz. Kilıçturgay K, Badur S, editörler, Viral Hepatit 2001, Istanbul, Viral Hepatitle Savaşım Derneği, 2001: p. 10-55.

11. Taşyaran MA, Akdağ R, Akyüz M et al. Erzurum yöresi çocuklarında fekal-oral bulaşan hepatit viruslarının seroprevalansı. Klimik Dergisi. 1994; 7: 74-8

12. Taşkesen M, Taş MA, Ecer $S$, Özel AK, Karabiberoğlu S. Akut Viral Hepatit A Olguların Klinik ve Laboratuar Bulgularının Değerlendirilmesi. Dicle Tıp Dergisi. 2008; 35(3): 155-8.

13. Uluğ M, Yaman Y, Yapıcı F, Uluğ C N. Çocuk Yaş Hrubu Akut Viral Hepatit A Olguları ve Komplikasyonlarının Irdelenmesi. Çocuk Enf Dergisi. 2010; 4: 65-70.

14. Devrim I, Memur Ş, Ziviş Z, Soylu Ö, Günay I, Dizdarer C, Ünal N. Akut Viral Hepatit Tanısı ile İlenen Hastalarımızın Değerlendirilmesi. J Pediatr Inf. 2011; 5: 4-6.

15. Geyik MF, Demirel M, Ayaz C, Kökoğlu ÖF, Hoşoğlu S. Akut Viral hepatitlerin klinik ve laboratuvar yönünden değerlendirilmesi. IV. Ulusal Viral Hepatit Simpozyumu 4-6 Kasım, Program ve Kongre Kitabı, Ankara, 1998. p.9. 